DOI: $10.1515 /$ rpp-2017-0016

Doctor of Pedagogical Sciences, Full Professor, NATALIYA MUKAN

Lviv Polytechnic National University, Ukraine Address: 12 Stepan Bandera St., Lviv, 79013, Ukraine

E-mail: nataliya.v.mukan@1pnu.ua

$\mathrm{PhD}$ in Pedagogical Sciences, Associate Professor, OLENA FUCHYLA

Lviv Polytechnic National University, Ukraine Address: 12 Stepan Bandera St., Lviv, 79013, Ukraine

E-mail: helenfuchila@gmail.com

Instructor, HALYNA IHNATIUK

Lviv Polytechnic National University, Ukraine Address: 12 Stepan Bandera St., Lviv, 79013, Ukraine

E-mail: halyna.ihnatiuk@gmail.com

\title{
CONSTRUCTIVIST APPROACH IN A PARADIGM OF PUBLIC SCHOOL TEACHERS' PROFESSIONAL DEVELOPMENT IN GREAT BRITAIN, CANADA, THE USA
}

\begin{abstract}
The article dwells on professional development of public school teachers as an inevitable constituent of education systems in the $21^{s t}$ century. In such economically developed countries as Great Britain, Canada and the USA, the problem of preparing teachers to a difficult and responsible task of upbringing and educating future citizens always remains topical. The authors define the following aim and objectives of their research: to conduct analysis of scientific and pedagogical literature and to define the notion of teachers' "professional development"; to research a place and role of the constructivist approach to professional development of teachers. Some aspects of the problem under research have been studied by foreign and domestic scientists: political, social, cultural and economic aspects of teachers' professional development (L. Darling-Hammond, M. Tight); elaboration of professional development curricula (C. Pratt); content of teachers' professional development (N. Dana Fichtman, S. Zepeda); concept-oriented instruction (J. Guthrie); continuing professional development (Ya. Belmaz, A. Kuzminskyi, O. Kuznietsova). The research methodology comprises theoretical (logical, structural and systematic methods, induction and deduction, comparison and compatibility, analysis and synthesis) and applied (observations, questioning and interviewing) methods. The research results have been presented.

Keywords: professional development, public school teachers, constructivist approach, Great Britain, Canada, the USA.

\section{INTRODUCTION}

A key task of the education system of any state is formulated as "preparing its citizens to functioning in the society. At the beginning of the $21^{\text {st }}$ century in the international educational space, this task not only keeps its actuality, but acquires a new meaning" (Mukan \& Fuchyla, 2016, p. 34).

Respectively, the problem of professional development (CPD) of public school teachers remains topical in the early $21^{\text {st }}$ century. It is a teacher whose deep knowledge,
\end{abstract}


skills and abilities, professional values and attitudes determine effectiveness of work with students, parents, colleagues, public representatives. Due to multifacetedness and complexity of this phenomenon, discussions on the theory, methodology and practice of public school teachers CPD are ongoing in scientific circles.

Upon generalization of foreign studies, the following conclusion can be drawn: professional development of teachers is a continuing process which covers three aspects, namely, initial preparation, introduction into the profession and constant improvement of personal, social and professional competencies of educators and corresponds to their career advancement.

Professional development is considered as a continuing process of lifelong learning and development which starts at initial stages of life and continues during studying at a higher education institution and after graduation from it (Dugger, Meade, Delaney, \& Nichols, 2003). It is also regarded as a plurality of different activities in which teachers take part individually or collectively with the aim to improve professional practice and encourage students learning (Sparks \& Hirsh, 2000). Professional development is a general combination of formal, non-formal and informal educational experience formed during the whole career path from initial pedagogical education to retirenment. CPD presupposes improving teachers' professionalism based on acquisition of professional knowledge, forming of professional awareness and attitudes, development of skills and abilities, competence. It is the very process which helps teachers acquire and broaden knowledge, skills and abilities of work with children, studying youth, colleagues at every stage of the pedagogical career (Day, 1999).

\section{THE AIM OF THE STUDY}

The article aims at researching specific features of applying the constructivist approach to CPD of public school teachers in Great Britain, Canada, the USA. The authors outline the following objectives: 1) to analyze scientific and pedagogical literature on the topic under research; 2) to specify the notion of educators' "professional development"; 3 ) to research place and role of the constructivist approach in teachers' CPD.

\section{THEORETICAL FRAMEWORK AND RESEARCH METHODS}

In our research, we have utilized various methods: analytical and critical (analysis of knowledge, skills, values and attitudes of public school teachers in the discourse of their professional development). The use of unification mechanism of the information obtained is a well-established approach to study the normative-legislative base, as well as scientific and pedagogical literature.

The scholars research different aspects of public school teachers' CPD: political, social, cultural and economic features (L. Darling-Hammond, M. Tight); the development of CPD programs (C. Pratt); CPD content (N. Dana Fichtman, M. Rees, A. Ross, S. Zepeda,); CPD models, forms and methods (K. Duinlan, P. Grimmet, G. Troia, P. Wong); teachers' activity during different periods of CPD (A. Charles, S. Farrell, R. Ingersoll) etc. Ukrainian researchers study the specificity of teacher training: continuing professional education (Ya. Belmaz, T. Desiatov), postgraduate education (A. Kuzminskyi, V. Russol), professional education (S. Honcharenko, R. Hurevych, N. Nychkalo), teacher training (T. Koshmanova, O. Semenog, Ye. Yevtukh), teachers' professional development (V. Bykov, N. Klokar, V. Oliinyk).

There are a number of instruments available for researching teachers' CPD. The comparative method is one of the most common procedures for determining specificity highlighted in educational documents, normative-legislative regulations, laws on education, CPD Standards and scientific-pedagogical literature. Induction and deduction were useful for gathering theoretical and factual material, its generalization, as well as realization and 
interpretation of separate phenomena of pedagogical reality. A number of comparative and compatible techniques have been used to define similarities in the content and operational components of teachers' CPD in the countries being studied.

Data have been collected using empirical methods of observation, questioning and interviewing teachers for gathering primary pedagogical information; interviewing and surveying research and teaching staff, administrative staff and students of educational departments, workers of teachers' associations and federations in Great Britain, Canada and the USA for clearing out specifics of organizing collaboration with schools; personal participation in workshops organized by Alberta Teachers' Association (Canada).

\section{RESULTS}

In our research, it has been revealed that there are differences between defining and interpreting the term "professional development" of teachers. It is connected with applying various theories, concepts and approaches.

There were some suggestions that professional development is a development of teachers' personality in a professional context with the help of accumulating experience and systematic analysis of their own pedagogical activity. CPD presupposes acquiring formal (e.g. participation in seminars, professional meetings, mentoring) and informal (e.g. reading, publishing, watching thematic documentary teleprograms) experience. While analyzing this experience, content of CPD, as well as its operational component and context in which it is realised are taken into account (Ganser, 2000). This concept defines CPD of a pedagogue as a growth occuring in the process of teacher's progression in accordance with the cycle of career development. CPD is a complex of activities performed systematically with the goal of preparing teachers to their professional activity. It encompasses initial preparation, curricula on introduction into the profession, postgraduate preparation, continuing professional development under school conditions (Scheerens, 2010). This view was echoed in OECD document which underlined that CPD is defined as an activity directed towards the development of individual skills and abilities, knowledge, experience and other traits of a teacher (2009).

These findings may help us to understand that professional development should be considered on the ground of applying systematic approach. In the course of comparative analysis of the systems of continuing pedagogical education in the countries under research, two unified levels of defining CPD of teachers (systemic and procedural) have been singled out to avoid differences and discrepancies in terminology. Thus, CPD of teachers is a multifaceted phenomenon and its main features correspond to an integral, dynamic and open system the main attributes of which are respective structure, aim and objectives, content, methods and forms directed towards acquiring professional knowledge, developing competencies from the beginning of the professional training and during the whole professional activity of a teacher and fulfilling a system of mastering competencies.

The observational study suggests that professional development of teachers is a process encompassing professional training in the conditions of a higher education institution, introduction into the profession and continuing improvement of educators' competencies within their whole career cycle. The aim of such development is to ensure professional, spiritual and physical improvement of a teacher who is a creator of the educational space in the $21^{\text {st }}$ century where their ideological principles of educational and cognitive activity are fulfilled.

The common principles on which teachers' professional development in the countries being studied is based have been revealed. The constructivist approach has been used mostly in adult education. Whereas pedagogy usually applies to the education of children, educators of adults use the term andragogy. Several lines of evidence suggest that 
it is not only difference in terms, but methods used in learning and teaching due to the fact that adults have much more experience and previously existing neurological structures. Approaches based on constructivism stress the importance of mechanisms for mutual planning, diagnosis of learner needs and interests, cooperative learning climate, sequential activities for achieving the objectives, formulation of learning objectives based on the diagnosed needs and interests. Personal relevance of the content, involvement of the learner in the process and deeper understanding of underlying concepts are some of the intersections between emphases in constructivism and adult learning principles (Constructivism (Philosophy of Education), n.d.).

Previous research has established that professional development of teachers in Great Britain, Canada, the USA is grounded on utilizing the constructivist concept which defines such development as an active process of constructing knowledge on the basis of educator's personal experience. The analysis proves commonality of applying a new perspective of pedagogues' professional development in the Anglophone countries determining its major principles. According to the constructivist paradigm, a teacher is considered as an active participant of the education process who is able to use in practice formed skills of teaching a subject, assessment, observation and critical analysis. The professional development is treated as a long-term process resulting into linkage of previous knowledge with new experience, which presupposes the whole cycle of learning. Systematic support is regarded to be "indispensable catalyst of the change process" (Schifter, Russell \& Bastable, 1999, p. 30).

Data from several sources have identified that particular interest of scientists is provoked by constructivism practiced as a philosophy of the process of person's knowledge construction. The British scholar R. Fox (2001) investigates the constructivist approach to learning in general and to professional development of teachers in particular. He believes that the major ideas of the constructivism are as follows: the process of cognition as an active process; knowledge refers to inventions not discoveries; any knowledge is personal and idiosyncratic (unique); knowledge construction has social character; learning in its essence is a process of finding a sense of life; effective learning is grounded on solving important open problems.

The most obvious finding emerging from this study is that according to constructivist ideas, taking into account natural abilities of students contributes to establishing an efficient education process; however, in addition to this, a teacher has to ensure the possibility to cooperate, communicate, solve problems and perceive new ideas and concepts. Learning from the perspective of constructivism is understood by a scholar as a thoughtful process of resolving internal cognitive conflicts which often become evident in certain cases of pedagogical activity, talks between colleagues, etc. In our view, learning is not only transfer of knowledge from one person to another. It is a personal self-conscious and transformational process in which new ideas, experience and personal judgements are integrated into new knowledge. It is worth noting that the active process of forming and development of professional communities of public school teachers which ensures an important toolkit for acquiring individual knowledge by an educator are common for Great Britain, Canada and the USA (Gordon, 2003).

Although both educators and politicians in the sphere of education understand the necessity of professional development of teachers, motivation to utilize its potential differs. M. Hashweh (2003) analyzes changes in professional activity of a teacher caused by evolutionary development of new concepts, hopes, expectations resulting from implementation of reforms in education. The author determines main conditions necessary for professional development of teachers in the system of continuing pedagogical education as follows: 
- internal motivation of educators to advance in qualification (awareness of differences between personal goals and practice);

- critical analysis of available knowledge, skills, attitude to the work of a teacher (awareness of the value of personal knowledge of theory and practice, lack of personal knowledge and need to acquire it);

- constructing new knowledge, developing skills, hopes and attitude of a teacher to the work (awareness of goals of the educational activity, practical application of knowledge, skills and abilities);

- cognitive reconstruction of knowledge (eliminating dissonance between premastered and new knowledge and realities of the modern time);

- creating social climate which would be favourable for professional development of public school teachers (cooperation between colleagues and research and teaching staff of universities, researchers in the educational sphere);

- respect and trust facilitating an open discussion of ideas and experience as one of major postulates of constructivism.

The results of this study indicate that according to the constructivist approach, S. Baker \& S. Smith (1999) determined the following main characteristics of professional development which most effectively contribute to implementation of changes into teachers' professioanl activity: identifying and achieving specific, realistic, problematic goals; activity which presupposes a combination of technical and conceptual aspects of teaching; support from colleagues; possibility to observe changes in the education process of students resulted from teacher's activity.

Content of pedagogical knowledge is a starting point in the process of "learning to teach." It means being able to differentiate a teacher of a subject from a specialist in the subject. The main idea of the principle of "learning to teach" consists in identifying linkages between subject knowledge and pedagogical knowledge and in the way of placing the subject knowledge in accordance with pedagogical logic. In the course of teaching, a subject is transformed with the help of teacher's activity through ways of presenting analogies, metaphors, issue articulation and demonstrations. The better a teacher understands the processes of mastering educational materials by students, the more effective their activity will be. One more element of the constructivist concept of learning is realising boundaries of context and social interaction which are connected with the development of a toolkit for realization.

Therefore, the constructivist pronciples of "learning to teach" presuppose diverse contexts in which awareness of a teacher can be developed. This awareness coincides with the process of learning where this awareness is utilized. "Learning to teach" often requires a specific content of teaching in certain situations and in the course of studying of particular students. There are some discussions on research and extended use of modelling, training, cooperative methods in class, microlearning, team learning. Such studying methods engage students into the context of reality where an active mode of learning is enabled and social knowledge forming is encouraged.

Moreover, P. Jenlink \& K. Kinnucan-Welsch (2001) consider a project in which specially created groups of professional development of the U.S. public school teachers took part. Due to stories about various situations in pedagogue's professional activity, the process was organised in such a way that the very participants were both students and teachers.

\section{CONCLUSIONS}

Orientation toward the constructivist approach to professional development of teachers and applying methods of empirical research enable considering the professional 
development of public school teachers from another point of view. First and foremost, it is awareness of professional development significance as a continuing process and acquiring additional professional experience with the help of which personal and professional development is carried out. The second, compelling in our view thesis is the importance of personal experience of public school teachers and stories about it analysis of which enables developing the theory of the pedagogy science. Stories about experience of pedagogical activity of particular educators establish the basis for developing critical thinking, contribute to the forming of conclusions.

Prospects for future research include the analysis of competence-based, axiological and intercultural approaches in a paradigm of public school teachers' continuing professional development in the countries under research.

\section{REFERENCES}

1. Baker, S., \& Smith, S. (1999). Starting off on the right foot: the influence of four principles of professional development in improving literacy instruction in two kindergarten programs. Learning disabilities research and practice, 14 (4), 239-253.

2. Constructivism (philosophy of education). Retrieved from https://en.wikipedia.org/ wiki/Constructivism_(philosophy_of_education).

3. Day, C. (1999). Developing teachers: the challenges of lifelong learning. London: Routledge.

4. Dugger, W., Meade, Sh., Delaney, L., \& Nichols, C. (2003). Advancing excellence in technological literacy. Arlington: Phi Delta Kappa, Inc.

5. Fox, R. (2001). Constructivism examined. Oxford review of education, 27 (1), 23-35.

6. Ganser, T. (2000). An ambitious vision of professional development for teachers. NASSP bulletin, 84 (618), 6-12.

7. Gordon, St. (2003). Professional development for school improvement: empowering learning communities. Texas: Allyn \& Bacon.

8. Guthrie, J.; et al. (2004). Increasing reading comprehension and engagement through concept-oriented reading instruction. Journal of educational psychology, 96 (3), 403-423.

9. Hashweh, M. (2003). Teacher accommodative change. Teaching and teacher education, 19, 421-434.

10. Jenlink, P., \& Kinnucan-Welsch, K. (2001). Case stories of facilitating professional development. Teaching and teacher education, 17, 705-724.

11. Mukan, N., \& Fuchyla, O. (2016). Functional literacy learning in the system of adult education in Belgium. Advanced education, 6, 34-39.

12. OECD. (2009). Creating effective teaching and learning environments: First Results from TALIS. Paris: OECD.

13. Scheerens, J. (2010). Teachers' professional development. Europe in international comparison. An analysis of teachers' professional development based on the OECD's teaching and learning international survey (TALIS). Luxembourg: Office for Official Publications of the European Union.

14. Schifter, D., Russell, S. J., \& Bastable, V. (1999). Teaching to the Big Ideas. In M. Z. Solomon (Ed.), the Diagnostic teacher: constructing new approaches to professional development (pp. 22-47). New York: Teachers College Press.

15. Sparks, D., \& Hirsh, S. (2000). Strengthening professional development. Education week, 19 (37), 42-45. 